Maja Biernacka

ORCID: https://orcid.org/0000-0003-3808-8864

Uniwersytet w Białymstoku

Instytut Socjologii

\title{
Agata Cieszewska, 2019, Green belts. Zielone pierścienie wielkich miast, Warszawa, Wydawnictwo Akademickie SEDNO, 296 stron, DOI 10.26343/9788379630868, recenzja książki
}

Odebrano / Received: 05.04.2021

Zaakceptowano / Accepted: 05.10.2021

Książka Agaty Cieszewskiej pod tytułem Green belts. Zielone pierścienie wielkich miast wydana została w 2019 roku nakładem Wydawnictwa Akademickiego Sedno. Stanowi ona próbę przedstawienia i systematyzacji wybranych instrumentów planistycznych, które nazywane są zbiorczym terminem green belts. Przyjęło się je tłumaczyć w polskiej literaturze przedmiotu jako zielone pierścienie. W wąskim znaczeniu termin ten stosowany jest w celu określenia okalających miasto niezabudowanych obszarów, które są wartościowe pod względem przyrodniczym i mają wysokie walory krajobrazowe oraz są atrakcyjne turystycznie, a jako takie spełniają ważne funkcje środowiskotwórcze.

Warto podkreślić, że nie chodzi jedynie o środowisko przyrodnicze rozumiane jako całokształt ożywionych oraz nieożywionych, a wzajemnie powiązanych składników przyrody, ale również sprawa dotyczy środowiska społecznego, a wraz z nim kulturowego, instytucjonalnego itd. Co więcej, podczas gdy polski przekład sugeruje, że struktura ma charakter domknięty, termin angielski ma szersze zastosowanie i dotyczyć może zarówno struktur domkniętych, półotwartych i otwartych, a ponadto przyjmujących różne kształty, czy to pasa, pasma czy klina. 
Autorka słusznie zwraca przy tym uwagę na fakt, że przyjęte w języku polskim określenie „pierścień” nie jest literalnym tłumaczeniem angielskiego wyrazu belt, który oznacza „pas”. Polska wersja językowa powstała jako bezpośrednie nawiązanie do inicjatywy zalesiania okalających stolicę gruntów w celu stworzenia Zielonego Pierścienia Warszawy. Podjęta została ona w ramach prac Biura Odbudowy Stolicy, wprowadzonych po drugiej wojnie światowej ze znaczącym wkładem wybitnego architekta i urbanisty Witolda Plapisa, któremu przypisuje się również zaproponowanie samego terminu. W związku z niespójnościami terminologicznymi, jakie wiążą się z powyższą różnicą, a dotyczyć mogą opisu poszczególnych form, autorka uznała za właściwe pozostawienie w języku polskim terminu „zielony pierścień” w odniesieniu do okalającego miasto pasa terenów zielonych i traktowanie go jako tłumaczenie angielskiego green belt, natomiast przy przedstawieniu rozwiązań przyjmujących inne kształty, zdecydowała się pozostać przy nazwach przyjętych w języku angielskim.

Poza modelem otaczającego miasto rdzeniowe zielonego pierścienia (green belt), wyszczególnia i omawia kolejno: model zielonych klinów (ang. green wedges), model zielonego serca (ang. green heart), model zielonego pierścienia obszarów chronionych (ang. green belt of protected areas), model sieci ekologicznej obszaru metropolitalnego (ang. green belt of ecological network) oraz model zewnętrznej granicy rozwoju zabudowy (ang. urban growth boundary). Przedstawione są one w postaci enumeracji, choć pierwszy $\mathrm{z}$ nich stanowi według terminologii przyjętej w języku angielskim kategorię obejmującą dwa spośród powyższych modeli.

Każde z tych rozwiązań planistycznych pozwala na swój sposób niwelować negatywne skutki urbanizacji, między innymi dzięki wymianie i poprawie jakości powietrza, retencji wody, a także ochronie i odtwarzaniu obszarów cennych pod względem różnorodności biologicznej oraz łączności ekologicznej i przyrodniczej w krajobrazie zarówno pod względem strukturalnym, jak i funkcjonalnym. Niebagatelna jest też ich rola w kształtowaniu środowiska społecznego. A mianowicie stanowić mogą one - i coraz częściej postrzegane są jako - obszary wielofunkcyjne, które mają zasadniczy wpływ na jakość życia w mieście. W szczególności zapewniają warunki do edukacji przyrodniczej i zwiększania świadomości ekologicznej, ale też pozwalają na promowanie i podtrzymywanie związanych z nią wartości oraz stylu życia obejmującego wypoczynek i uprawianie sportu na świeżym powietrzu, a w konsekwencji pozwalają na krzewienie w społeczeństwie kultury zdrowotnej. Pozwalają też na uprawę płodów rolnych, skracając łańcuch w relacjach producent - konsument bądź pozwalają na łączenie ich funkcji poprzez prosumpcje, czyli bycie jednocześnie producentem i konsumentem dóbr.

Wdrażanie tego rodzaju instrumentów, a także prowadzenie badań naukowych na ich temat staje się coraz bardziej naglącą potrzebą w obliczu konieczności zatrzymania kryzysu klimatycznego, procesów degradacji środowiska naturalnego oraz zanikania gatunków. Gdy mowa o środowisku przyrodniczym, sprawa dotyczy przede wszystkim niwelowania negatywnych skutków urbanizacji i tak zwanego „rozlewania się miast”, jak określa się ten proces w ślad za angielskim terminem urban sprawl. 
Cieszewska prezentuje ewolucję koncepcji zielonego pierścienia począwszy od traktowania go w XIX wieku jako remedium na niepokojący stan higieny życia w wielkich miastach, wynikający zwłaszcza z braku kanalizacji i dostępu do czystej wody, a także zanieczyszczenia powietrza oraz niedostatku powszechnie dostępnych miejsc wypoczynku. Interesująco pisze o wypracowywaniu i wdrożeniach pierwszych rozwiązań planistycznych tego rodzaju w pierwszej połowie XX wieku, aby wreszcie omówić ewolucję koncepcji w drugiej połowie XX i na początku XXI wieku, związanej z procesami decentralizacji miast oraz powstania współczesnej struktury miasta metropolitarnego. Podkreśla, że obok funkcji strukturotwórczej, która obejmuje ochronę terenów otwartych, eksponowane jest wspó́cześnie znaczenie budowania powiązań przyrodniczych, które zapewniają podtrzymanie migracji gatunków między miastem a strefą podmiejską. Wskazuje na renesans funkcji żywicielskiej, choć w jej nowym wydaniu, to jest jako związanej z rozwojem rolnictwa miejskiego, a także funkcji higienicznej, polegającej na utrzymaniu czystych i zdrowych terenów otwartych okalających miasta, co jest tym bardziej istotne wraz ze zmianami klimatu, które sprawiają, że zielonym pierścieniom przybywa funkcji.

Autorka przedstawia zróżnicowanie sposobów zastosowania koncepcji zielonego pierścienia tworzonego wokół miast lub w obrębie tkanki miejskiej, podpierając się szczegółowo omawianymi przykładami z różnych części świata, zarówno z Europy, Azji, Australii, jak i Ameryki Północnej oraz Południowej. Jeśli chodzi o Europę, dotyczy to Londynu, Manchesteru, Paryża, Berlina, Wiednia, Frankfurtu, Rzymu, Kopenhagi, Sztokholmu oraz Randstadu, czyli niezabudowanej przestrzeni między Amsterdamem, Rotterdamem i Utrechtem. Przykłady azjatyckie to Pekin, Hongkong, Seul, Tokio, australijskie - Sydney, Adelaide i Melbourne, a amerykańskie - Portland, San Francisco, Austin, Ottawa, Ontario's Greenbelt, stanowiącego tereny chronione na południu prowincji Ontario, a ponadto São Paulo. Po ich szczegółowym omówieniu autorka podjęła się wypracowania zestawu modeli zielonych pierścieni, które stosowane są na świecie, wraz z ich charakterystyką i zestawem pełnionych funkcji, a następnie omówiła dobre praktyki i specyfikę najbardziej skutecznych rozwiązań.

Na szczególną uwagę zasługuje część książki, w której Cieszewska - posłużywszy się dziesięcioma europejskimi studiami przypadku oraz dodatkowo przykładem Warszawy - analizuje potencjał środowiska przyrodniczego do kształtowania zielonych pierścieni w wybranych strefach buforowych miast. Za cel stawia sobie zweryfikowanie, czy w otoczeniu miast, w których wdrożona została koncepcja zielonych pierścieni, faktycznie występuje specyficzna dla niej struktura przestrzenna, cechująca się określonym udziałem terenów rolnych, ekosystemów naturalnych i półnaturalnych oraz terenów antropogenicznych. Czyni to poprzez analizę sposobów użytkowania oraz określenie wskaźników krajobrazowych umożliwiających ocenę potencjału tych terenów do pełnienia czterech podstawowych funkcji zielonych pierścieni: żywicielskiej, środowiskotwórczej, ekologicznej i rekreacyjnej.

W badaniu struktury krajobrazu w obszarach metropolitalnych $\mathrm{z}$ koncentracją na sposobach użytkowania i pokrycia terenu autorka posłużyła się bazą CORINE Land 
Cover (CLC) dla roku 2006, z przyjętym poziomem szczegółowości na poziomie 3., w którym dla całej Europy wyróżniono 44 klasy pokrycia terenu. Źródłem wykorzystanych przez nią danych były zasoby Europejskiej Agencji Środowiska (European Environment Agency, EEA). Dane te zostały zweryfikowane za pomocą interpretacji wizualnej zobrazowań satelitarnych. Ponieważ w przypadku dwóch ośrodków miejskich - Londynu i Manchesteru - dane z 2006 roku nie były dostępne, aby uzyskać porównywalny materiał, wykorzystano i poddano aktualizacji dane CORINE Land Cover z 2000 roku. Autorka ma świadomość ograniczeń rozdzielności tej bazy utrudniających czy uniemożliwiających mapowanie mapowania i czyni wzmiankę o dyskusji na ten temat $\mathrm{w}$ literaturze przedmiotu. Uznaje natomiast pozyskany materiał jako wystarczająco szczegółowy na użytek swej publikacji. W przeprowadzonych analizach wykorzystane zostały równieżdane oinnych cechach środowiska związanych zukształtowaniem terenu oraz formami ochrony przyrody. Źródło informacji o ukształtowaniu terenu stanowił numeryczny model terenu SRTM (Shuttle Radar Topography Mission), który został uzyskany z portalu CIGIAR-CSI (CGLAR Consortium for Spatial Information). Dane zostały opracowane przez NASA/USGS (U.S. Geological Survey) w 2003 roku. Autorka wykorzystała wersję numerycznego modelu terenu 4.1 z 2008 roku, w której oryginalne dane zostały poddane dodatkowej korekcie w postaci uzupełnienia brakujących informacji wysokościowych. Pobrane zostały arkusze o rozpiętości 5 stopni, które zostały następnie zmozaikowane, czyli połączone w celu uzyskania ciągłości przestrzennej analiz. Jeśli chodzi natomiast o ochronę przyrody, jako jej jednolite formy dla całej Europy przyjęto obszary Natura 2000, określone na podstawie EUNIS (The European Nature Information System) Natura 2000, z bazy danych dostępnej na stronie EEA aktualizowanej w 2012 roku.

Następnie Cieszewska rozważa możliwości wdrożenia w Polsce koncepcji zielonych pierścieni. W tym celu poddaje analizie potencjał środowiska przyrodniczego wybranych miejskich obszarów funkcjonalnych, to jest tam, gdzie tego rodzaju struktury mogą zostać wypracowane zgodnie z założeniami Koncepcji Przestrzennego Zagospodarowania Kraju (KPZK 2030). Przeprowadzona została ona podobnie jak poczyniono to w odniesieniu do przypadków miast w innych państwach europejskich. Przy tym na użytek analizy potencjału kształtowania zielonych pierścieni w miejskich obszarach funkcjonalnych największych miast Polski wykorzystano dane $z$ innych źródeł niż w przykładach europejskich. Autorka opierała się na materiałach pozyskanych z Bazy Danych Obiektów Ogólnogeograficznych (BDOO), z aktualizacją z 2011 roku. Analizy obejmowały właściwości pokrycia terenu, jego ukształtowania, a także występowania wód oraz obszarów chronionych. Zawartość w bazie informacji o granicach administracyjnych pozwoliła autorce przyjąć za pola odniesienia nowe granice miejskich obszarów funkcjonalnych, a nie strefy buforowe, jak poczyniono w europejskich studiach przypadków. Pociąga to za sobą dodatkowe różnice metodologiczne. Sprawa w szczególności dotyczy odmiennych kategorii pokrycia terenu w BDOO niż te, które zastosowano 
w CORINE Land Cover, co zostało nie tylko zasygnalizowane w książce, ale usystematyzowane w postaci tabelarycznego porównania tychże kategorii.

Zestawienie umożliwiło zweryfikowanie, na ile struktura przestrzenna okalająca największe polskie ośrodki przypomina strefy buforowe, gdzie została już wprowadzona w życie koncepcja kształtowania zielonych pierścieni. Następnie autorka dokonała przeglądu zastosowanych rozwiązań $w$ polskich miejskich obszarach funkcjonalnych oraz przedstawiła studium przypadku,którego przedmiotem jest MiejskiObszar Funkcjonalny Ośrodka Wojewódzkiego Warszawy wraz z delimitacją zielonego pierścienia Warszawy.

Książka Agaty Cieszewskiej dotyczy rozwiązań planistycznych, które wypracowywane są i poddawane dyskusji nie tylko na poziomie poszczególnych ośrodków miejskich, ale też struktur państwowych i ponadpaństwowych. W kontekście działań Unii Europejskiej tematyka ta wpisywać się powinna znakomicie w nową strategię rozwoju o nazwie Europejski Zielony Ład. W zasadzie sprowadza się on jak dotąd do określenia przez instytucje unijne ogólnych założeń, celów i kierunków rozwojowych, które wypracowane zostały już po publikacji tej książki. Poruszane problemy z pewnością powracać będą wobec konieczności podejmowania konkretnych działań wdrożeniowych na poziomie poszczególnych państw UE i różnych szczebli władzy, w tym samorządów miejskich.

Publikacja ta może zainteresować nie tylko urbanistów, zwłaszcza zajmujących się kształtowaniem terenów zielonych oraz ekologów, geografów, ale także ekonomistów i socjologów zainteresowanych sposobami oraz tendencjami kształtowania tkanki miejskiej. Stanowi też cenną lekturę dla przedstawicieli władz i działaczy społecznych oraz samorządowych, dla których nie jest obojętny stan środowiska naturalnego. Warto ją też czytać przez pryzmat potencjału badawczego na użytek prac interdyscyplinarnych, zwłaszcza łączących kompetencje specjalistów z zakresu gospodarki przestrzennej z tymi, których osią zainteresowań jest czynnik ludzki.

\section{Autorka:}

Dr hab. Maja Biernacka

Zakład Socjologii Organizacji i Instytucji

Instytut Socjologii

Uniwersytet w Białymstoku

Plac Niezależnego Zrzeszenia Studentów 1, 15-403 Białystok

e-mail: m.biernacka@tlen.pl 
